\title{
Photodegradation of fluorescent dissolved organic matter in river waters
}

\author{
Khan M. G. Mostofa, ${ }^{1,2 * *}$ TAKahito Yoshioka, ${ }^{1 *}$ EIICHI Konohira ${ }^{1 \dagger}$ and EIICHIRo TANoue ${ }^{1 \ddagger}$ \\ ${ }^{1}$ Institute for Hydrospheric-Atmospheric Sciences, Nagoya University, Nagoya 464-8601, Japan \\ ${ }^{2}$ Graduate School of Biosphere Science, Department of Environmental Dynamics and Management, Hiroshima University, \\ 1-7-1, Kagamiyama, Higashi-Hiroshima 739-8521, Japan
}

(Received February 19, 2007; Accepted June 26, 2007)

\begin{abstract}
Photodegradation of dissolved organic matter (DOM), collected from two upstream and one downstream sites in the Lake Biwa watershed in Japan, was investigated using fluorescence properties of three-dimensional excitation emission matrix (3-D EEM). Solar irradiation caused a decrease in the dissolved organic carbon (DOC) concentration and in the fluorescence peak intensity (FI) of fulvic acid (FA)- and protein-like substances in DOM. Mineralization of DOC during an irradiation period (13 days) was observed to be higher in upstream samples (32-36\%) compared to that in downstream sample (16\%). DOC concentration in samples stored in the dark significantly decreased in the downstream sample (16\%), while those in upstream samples hardly decreased (1-8\%). The FI of FA-like substance decreased by $72-84 \%$ during $13-$ days irradiation (integrated solar intensity $=176 \mathrm{MJ} \mathrm{m}^{-2}$ ). The protein-like fluorescence was only observed in the downstream sample and the net decrease in the FI was 59\% in the irradiated sample. The first-order reaction kinetics was applied to analyze the photodegradation of DOM. Two-step photodegradation was suggested for the fluorescent DOM (FDOM), while not for the DOC. Results obtained here suggested that FA-like FDOM is more susceptible to photodegradation compared with those of protein-like substances and DOC.
\end{abstract}

Keywords: dissolved organic carbon, fulvic acid-like fluorescence, protein-like fluorescence, photodegradation, streams

\section{INTRODUCTION}

The major components of dissolved organic matter (DOM) in freshwaters are humic substances, carbohydrates and amino acids (Steinberg and Münster, 1985; Malcolm, 1985; Volk et al., 1997; Baker, 2001; Baker and Spencer, 2004; Engelhaupt and Bianchi, 2001). The dominant fractions of humic substances (HS) in DOM are fulvic acids (FA) which are ubiquitous in natural aquatic ecosystems (Malcolm, 1985; Senesi, 1990). Although the composition of DOM can vary temporally and spatially, $\mathrm{HS}$ is, in general, the most abundant in stream waters $(50 \sim 80 \%)$, and the ratio of FA to humic acid (HA) is generally as high as 9:1 (Malcolm, 1985). FA has highly complex chemical structures and variable composition (Malcolm, 1985, 1990; Senesi, 1990; Münster et al., 1999). The molecular structure of FA has been identified

\footnotetext{
*Corresponding author (e-mail: yoshioka@kais.kyoto-u.ac.jp) * Present address: Field Science Education and Research Center, Kyoto University, Kitashirakawa, Oiwake, Kyoto 606-8502, Japan. **Present address: Institute of Geochemistry, The Chinese Academy of Sciences, 46 Guanshui Road, Guiyang/Guizhou 550002, China. ${ }^{\dagger}$ Present address: NPO Mori-no-za, Ina 396-0011, Japan. ‡Present address: Graduate School of Environmental Studies, Nagoya University, Nagoya 464-8601, Japan.

Copyright @ 2007 by The Geochemical Society of Japan.
}

as benzene containing carboxyl, methoxylate and phenolic groups, hydroxycoumarin-like structures, and fluorophores containing the Schiff-base system, chromone, xanthone, and quinoline derivatives (Senesi, 1990; Leenheer and Croue, 2003). On the other hand, amino acids in freshwaters have been detected in a combined form, mostly humic bound or colloidal in river waters (Volk et al., 1997; Baker et al., 2007) and affected by anthropogenic sources (Baker, 2001, 2002a, 2002b; Mostofa et al., 2005a). FA- and protein-like substances are the major components of the fluorescent dissolved organic matter (FDOM) in natural waters (Senesi, 1990; Coble, 1996; Yamashita and Tanoue, 2003 and references therein). The florescent components such as FA- and protein-like substances have been investigated by the three-dimensional excitation emission matrix (3-D EEM). Due to simplicity of the 3-D EEM technique, it is now widely used for characterization of FDOM and for determinations of the nature, sources and quantity of FDOM in natural waters (Baker, 2001, 2002a; Coble, 1996; Yamashita and Tanoue, 2003; Mostofa, 2005; Mostofa et al., 2005a, b). The 3D-EEM of FA- or humiclike substances in the aquatic DOM, in general, has been shown a major fluorescence peak within a range of excitation/emission (Ex/Em) wavelengths of 320-390/420 $490 \mathrm{~nm}$ (Coble et al., 1990; Senesi, 1990; Leenheer and Croue, 2003; Coble, 1996; McKnight et al., 2001). 
Protein-like fluorescence peaks have been detected at Ex/ $\mathrm{Em}=$ 280-285/321-360 nm (Baker, 2001, 2002a; Coble, 1996; Yamashita and Tanoue, 2003).

It was reported that the fluorescence properties of terrestrial FDOM changed due to natural solar effects from upstream to the lacustrine environments at the watershed level (Mostofa et al., 2005b; Hayakawa et al., 2003). The upstream DOM has unique characteristic properties due to the sole sources of origin, such as forests or swamp ecosystems (Steinberg and Münster, 1985; Malcolm, 1985, 1990). But the DOM in downstream waters is a mixture with various kinds of origins, such as upstream waters, agricultural fields, urban activities, and autochthonous input. Considering these differences in sources of DOM among stream waters, it is of interest to investigate alterations of DOM and FDOM in the aquatic environment. Yoshioka et al. (2007) reported the systematic changes in the molecular size of DOM and in the fluorescence peak position between river and lake waters. Solar and biological processes might affect the molecular size and fluorescence property of DOM components. Photodegradation of DOM and FDOM have been reported in river (Amon and Benner, 1996; Mostofa et al., 2005b) and coastal waters (Moran et al., 2000; Vähätalo and Wetzel, 2004). Amon and Benner (1996) described photodegradation of DOC in river waters, but they did not discuss fluorescence properties of FDOM. Studies on the photodegradation of FDOM are still limited.

In this study, solar irradiation experiments were conducted for upstream and downstream waters collected from the Lake Biwa watershed in the central Honshu Island in Japan. This study investigated the photochemical alterations of the fluorescence properties of FA-like and protein-like substances in FDOM and DOC concentrations during a 13-day irradiation period. The spatial differences in the photodegradation kinetics of DOC and FDOM between upstream and downstream waters were also discussed in this study.

\section{Materials ANd Methods}

\section{Sampling}

Water samples were collected from two upstreams, the Kago (KG) and the Nishi-Mataya (NM), and one downstream, the Yasu River (YR) in the Lake Biwa watershed $\left(35^{\circ} 15^{\prime} \mathrm{N}, 136^{\circ} 05^{\prime} \mathrm{E}\right)$, Japan (Fig. 1). KG is situated in the upstream of Seta River, and NM is situated in the upstream of Ane River (Fig. 1). Yasu River is the longest river $(64 \mathrm{~km})$ among all the rivers existed in the Lake Biwa watershed and its drainage area is $366 \mathrm{~km}^{2}$ (Fig. 1). Upstream waters originate through leaching of groundwater from high mountainous regions, which are densely shaded with mixed forests growing on granitic substrates. The waters in the downstream river are drained from dif-

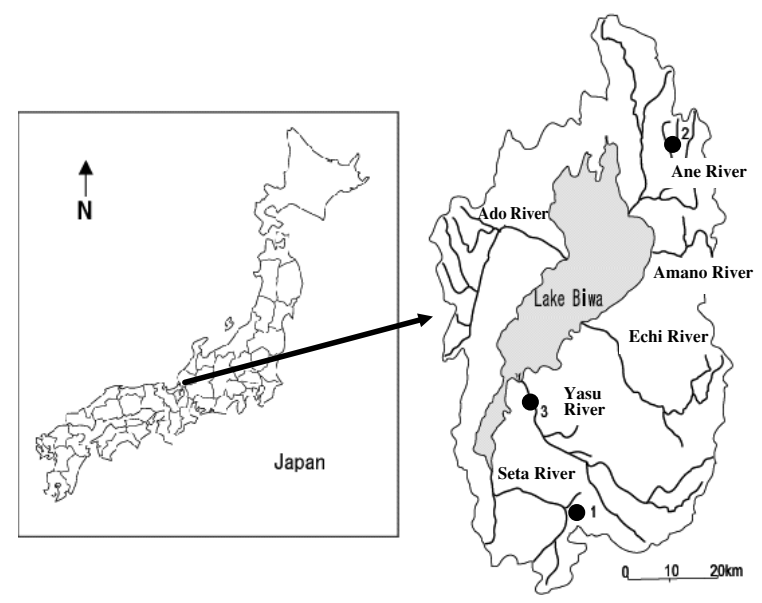

Fig. 1. Lake Biwa watershed, Japan and water sampling sites of the Kago (KG) upstream (site 1), the Nishi-Mataya (NM) upstream (site 2) and the Yasu River (YR) downstream (site 3 ).

ferent sources at downstream sites, such as agricultural fields and artificial land covers along the river as well as from the upstream region. There were several reasons to choose two upstream sites (KG and NM) and the downstream site (YR). The level of DOC concentration in KG (about $100 \mu \mathrm{M} \mathrm{C}$ ) was the highest among upstream sites in the Lake Biwa watershed, while that in NM (about 40 $\mu \mathrm{M} \mathrm{C})$ was medium, although fluorescence properties were quite similar among sites in upstream regions (Mostofa et al., 2005b). The YR showed the highest level of DOC concentration ( $200 \mu \mathrm{M} \mathrm{C})$ among all the rivers existed in the Lake Biwa watershed, except for small channels (Mostofa et al., 2005b).

Polycarbonate bottles were used to collect samples. After sampling, bottles were covered with black polyethylene bags to protect the water samples from the solar radiation until the photodegradation experiment. Water samples were filtered with precombusted $\left(450^{\circ} \mathrm{C}\right)$ glass-fiber filters (GF/F, Whatman, Maidstone, UK). Quartz bottles (100 $\mathrm{ml}$ in volume) were used for solar radiation and glass bottles (100 $\mathrm{ml}$ in volume) were used for dark incubation for water samples. The polycarbonate, quartz, and glass bottles were cleaned with an alkaline detergent (2\% solution of Extran MA O3, Merck Japan, Tokyo, Japan), hot water, and pure water (Milli Q TOC, Millipore, Tokyo, Japan). The quartz and glass bottles were then combusted at $450^{\circ} \mathrm{C}$ for $2 \mathrm{~h}$.

\section{Experimental design}

The photodegradation experiment was conducted from May 20 to June 1, 2001 on the roof of the Institute for Hydrospheric-Atmospheric Sciences, Nagoya University, Japan. To examine the effects of solar radiation, fifteen 
quartz bottles were filled with the filtered water ( $c a .100$ ml) of each sample, sealed with Teflon-coated butylrubber stoppers and aluminum caps, and then submerged into an in-flow water bath, in which tap water was continuously supplied to control the water bath temperature (Mostofa et al., 2005b). Fifteen glass bottles were filled with sample water and sealed with Teflon-coated butylrubber stoppers and aluminum caps. As a control experiment under the dark condition, these glass bottles were wrapped with aluminum foil and placed in the same bath. The daily solar incident intensity during the experiment was measured using a Pyranometer (MS-801F, EKO Instruments Co. Ltd., Tokyo, Japan). The temperature in the water bath was recorded using a thermo recorder (TR$71 \mathrm{~S}, \mathrm{~T} \& \mathrm{D}$ corporation, Matsumoto, Japan). During the experiments, the water bath temperature fluctuated between 25 and $35^{\circ} \mathrm{C}$.

Incubated bottles were withdrawn in triplicate for each treatment after $1,4,7,10$, and 13 days of irradiation. Integrated solar intensities at the respective days were 22, $44,92,141$, and $176 \mathrm{MJ} \mathrm{m}^{-2}$. For the DOC concentration measurement, the $15 \mathrm{ml}$ of water sample from each sample bottle was poured into the brown glass bottle $(30 \mathrm{ml}$ in volume) in triplicate. Twenty-five $\mu 1$ of $6 \mathrm{~N} \mathrm{HCl}$ solution was added to remove dissolved inorganic carbon (DIC). For fluorescence measurement, about $6 \mathrm{ml}$ of each sample was introduced to the small brown bottle $(10 \mathrm{ml}$ in volume) in duplicate. These bottles were sealed with Teflon-coated butyl-rubber stoppers and aluminum caps, stored in a freezer $\left(-40^{\circ} \mathrm{C}\right)$, and analyzed within seven days.

\section{Analytical methods}

DOC concentration was measured using a hightemperature catalytic oxidation method (Yoshioka et al., 2002). System blanks were determined according to the software installed in the TOC 5000 A (Shimadzu Co. Ltd., Kyoto, Japan). System blanks and pure water blanks were on average 2-4 $\mu \mathrm{M} \mathrm{C}$ and $6 \mu \mathrm{M} \mathrm{C}$, respectively. To calculate the DOC concentration, only system blanks were used for data correction.

EEMs of samples were measured using a fluorescence spectrophotometer (F-4500, Hitachi Ltd., Tokyo, Japan), according to previous research (Mostofa et al., 2005b). The scanning ranges were $225-400 \mathrm{~nm}$ for excitation (Ex) and 225-500 nm for emission (Em). Readings were collected at intervals of $5 \mathrm{~nm}$ Ex with $1 \mathrm{~nm}$ Em wavelength. The wavelength accuracy was within $\pm 2 \mathrm{~nm}$. The fluorescence spectra were measured in triplicate and were averaged for each sample. Fluorescence intensities (FI) of water samples were calibrated as quinine sulfate unit (QSU) using the fluorescent intensity of quinine sulfate solution (the FI of $4 \mu \mathrm{g} \mathrm{liter}^{-1}$ quinine sulfate solution $=$ $4 \mathrm{QSU}$ ) at $\mathrm{Ex} / \mathrm{Em}=350 / 450 \mathrm{~nm}$.
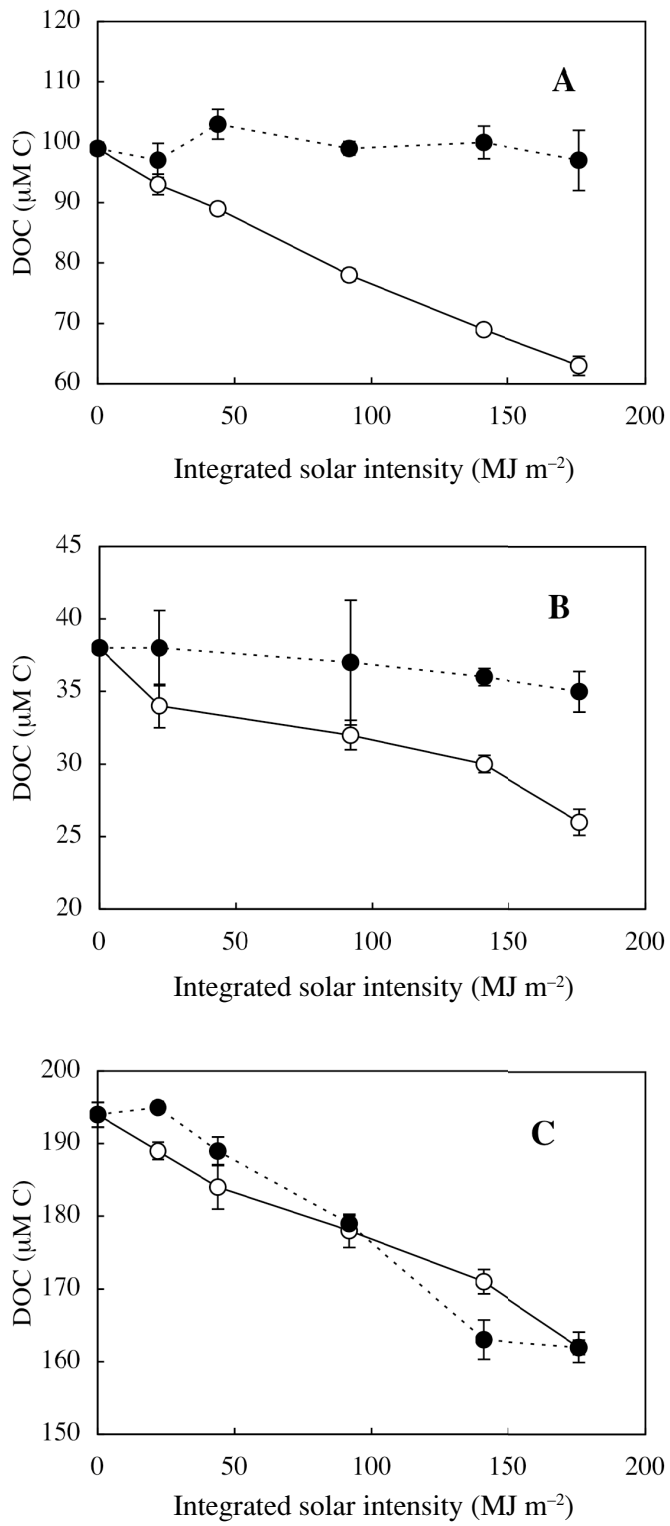

Fig. 2. Changes in the DOC concentrations with the integrated solar intensity. A, the KG upstream; $B$, the NM upstream; $C$, the YR downstream samples. Open circle, irradiated condition; closed circle, dark condition. The error bar indicates the standard deviation.

\section{RESULTS AND DISCUSSION}

\section{Photodegradation of DOC}

DOC concentrations of original samples (before irradiation) were $99 \mu \mathrm{M} \mathrm{C}$ in the $\mathrm{KG}$ upstream, $38 \mu \mathrm{M} \mathrm{C}$ in the NM upstream, and $194 \mu \mathrm{M} \mathrm{C}$ in the YR downstream, respectively. DOC concentrations gradually decreased during the exposure to the sunlight (Fig. 2). At the end of the experiment (integrated solar intensity $=176 \mathrm{MJ} \mathrm{m}^{-2}$ ), DOC concentrations decreased by $36 \%$ in the $\mathrm{KG}, 32 \%$ 
Table 1. Comparison of the decreases in DOC and FI of FA-like (peak C) and protein-like (peak T) fluorescence during the irradiation period between this study and reported studies

\begin{tabular}{|c|c|c|c|c|c|}
\hline \multirow[t]{2}{*}{ Samples } & \multirow[t]{2}{*}{ Irradiation time } & \multirow[b]{2}{*}[\mathrm{DOC}]{} & \multicolumn{2}{|c|}{ Decrease $(\%)$} & \multirow[t]{2}{*}{ References } \\
\hline & & & FI of peak C & FI of peak $\mathrm{T}$ & \\
\hline \multicolumn{6}{|l|}{ This study } \\
\hline \multicolumn{6}{|l|}{ Irradiated condition } \\
\hline KG & 13 days & 36 & 72 & nd & \\
\hline NM & 13 days & 32 & 84 & nd & \\
\hline YR & 13 days & 16 & 80 & 59 & \\
\hline \multicolumn{6}{|l|}{ Dark condition } \\
\hline KG & 13 days & 1 & $15^{*}$ & nd & \\
\hline NM & 13 days & 8 & $6^{*}$ & nd & \\
\hline YR & 13 days & 16 & $14^{*}$ & $6^{*}$ & \\
\hline \multicolumn{6}{|l|}{ Reported studies } \\
\hline \multicolumn{6}{|l|}{ Irradiated condition } \\
\hline Rio Negro & 75 hours & 15 & nd & nd & Amon and Benner, 1996 \\
\hline Satilla Estuary & 70 days & $31 \sim 36$ & $53 \sim 56$ & $37 \sim 45$ & Moran et al., 2000 \\
\hline Lake Tuscaloosa & 42 days & 41 & nd & nd & Vähätalo and Wetzel, 2004 \\
\hline \multicolumn{6}{|l|}{ Dark condition } \\
\hline Rio Negro & 75 hours & $1.2 \sim 2.7$ & nd & nd & Amon and Benner, 1996 \\
\hline Satilla Estuary & 51 days & $3 \sim 9$ & $0.5 \sim 12$ & $12 \sim 23^{*}$ & \\
\hline Lake Tuscaloosa & 42 days & nd & nd & nd & Vähätalo and Wetzel, 2004 \\
\hline
\end{tabular}

nd: not detected.

*The increase in FI of peak $C$ or peak $T$ during the incubation period.

in the NM and $16 \%$ in the YR samples (Table 1). Under the dark condition, DOC concentration hardly changed in upstream samples (Figs. 2A and 2B). Therefore, the irradiation caused almost all decrease in DOC in the upstream samples. On the other hand, the DOC concentration of YR sample significantly decreased by $16 \%$ under the dark condition as much as under the irradiated condition (Fig. 2 and Table 1). It suggested that the photodegradation was not effective in the downstream sample of YR. In reported studies on the photodegradation of DOC, the decrease in the DOC concentration in the irradiated samples was $15-41 \%$ of the initial DOC concentration during the irradiation period (Table 1), while that in the dark sample was less than $10 \%$. Results of KG and NM samples were similar to those in previous studies (Figs. 2A and 2B). On the other hand, the degradation of the downstream DOC might be due to the microbial activity, because the DOC concentration decreased under the dark condition as well as under the light condition (Fig. 2C). It can be noted that the labile DOM (LDOM) is mostly comprised of dissolved free amino acids, carbohydrates, fatty acids, glucose, aldehydes, oxalate, glyoxalate, few vitamins, steroids, and pesticides (Moran and Zepp, 1997; Mann and Boddy, 2000; Ogawa et al., 2001). These LDOMs might be introduced into the downstream area of Yasu River from urban and agricul- tural areas along the downstream locations. On the other hand, the refractory nature of upstream DOM to microbial degradation suggested the existence of large quantity of humic substances (fulvic and humic acids).

\section{Photodegradation of FDOM}

The 3-D EEM of original samples exhibited a major fluorescence peak at $E x / E m=333 \pm 3 / 472 \pm 5 \mathrm{~nm}$ in the KG upstream, $340 \pm 5 / 458 \pm 3 \mathrm{~nm}$ in the NM upstream, and $340 / 435 \pm 3 \mathrm{~nm}$ in the YR downstream samples (Table 2 and Fig. 3). The peaks of upstream samples resembled those of the humic-like fluorescence, the "peak C" $(E x / E m=350 / 420-480 \mathrm{~nm})$ in seawater $($ Coble, 1996$)$ or standard Suwannee River fulvic acid fluorescence peak $($ Excitation/Emission $=333 \pm 3 / 469 \pm 6 \mathrm{~nm}$, Mostofa $e t$ $a l ., 2005 \mathrm{a})$. The peak in the YR downstream sample was similar to the peak $C$ of emission wavelengths (441 449 $\mathrm{nm}$ ) in waters from U.K. river (Baker and Spencer, 2004). Protein-like (tryptophan-like) peak "peak T" was detected at $\mathrm{Ex} / \mathrm{Em}=280 / 338 \pm 2 \mathrm{~nm}$ in the original YR downstream sample (Fig. 3B). However, the peak T was not found in the KG and NM upstream samples.

During the consecutive irradiation period, Ex and Em wavelengths of the fluorescence peak $\mathrm{C}$ in irradiated samples gradually shifted from longer to shorter wavelength regions, i.e., blue-shift of the peak position (Table 2). One- 
Table 2. Changes in fluorescence peak position during the experiment

\begin{tabular}{|c|c|c|c|c|c|c|}
\hline \multirow[t]{2}{*}{ Samples } & \multirow{2}{*}{$\begin{array}{c}\text { Irradiation time } \\
\text { days }\end{array}$} & \multirow{2}{*}{$\begin{array}{c}\text { ISI } \\
\left(\mathrm{MJ} \mathrm{m}^{-2}\right)\end{array}$} & \multicolumn{2}{|c|}{ Peak C position (Ex/Em: nm) } & \multicolumn{2}{|c|}{ Peak T position (Ex/Em: nm) } \\
\hline & & & Irradiated condition & Dark condition & Irradiated condition & Dark condition \\
\hline \multicolumn{7}{|l|}{$\mathrm{KG}$} \\
\hline & 0 & 0 & $333 \pm 3 / 472 \pm 5$ & $333 \pm 3 / 472 \pm 5$ & nd & nd \\
\hline & 1 & 22 & $318 \pm 3 / 446 \pm 9$ & $338 \pm 8 / 465 \pm 2$ & nd & nd \\
\hline & 4 & 44 & $315 / 441 \pm 1$ & $337 \pm 6 / 469 \pm 8$ & nd & nd \\
\hline & 7 & 92 & $313 \pm 3 / 437 \pm 5$ & $340 / 468 \pm 5$ & nd & nd \\
\hline & 10 & 141 & $310 / 429$ & $342 \pm 8 / 463 \pm 2$ & nd & nd \\
\hline & 13 & 176 & $308 \pm 6 / 433 \pm 4$ & $335 \pm 5 / 465 \pm 2$ & nd & nd \\
\hline \multicolumn{7}{|l|}{ NM } \\
\hline & 0 & 0 & $340 \pm 5 / 458 \pm 3$ & $340 \pm 5 / 458 \pm 3$ & nd & nd \\
\hline & 1 & 22 & $317 \pm 3 / 448 \pm 13$ & $345 / \pm 5 / 459 \pm 10$ & nd & nd \\
\hline & 4 & 44 & $312 \pm 3 / 427 \pm 4$ & $342 \pm 8 / 465 \pm 13$ & nd & nd \\
\hline & 7 & 92 & $312 \pm 3 / 427 \pm 4$ & $342 \pm 8 / 465 \pm 13$ & nd & nd \\
\hline & 10 & 141 & $310 \pm 5 / 423 \pm 1$ & $343 \pm 6 / 461 \pm 1$ & nd & nd \\
\hline & 13 & 176 & $312 \pm 3 / 418 \pm 2$ & $345 / 473 \pm 8$ & nd & nd \\
\hline \multicolumn{7}{|l|}{ YR } \\
\hline & 0 & 0 & $340 / 435 \pm 3$ & $340 / 435 \pm 3$ & $280 / 338 \pm 2$ & $280 / 338 \pm 2$ \\
\hline & 1 & 22 & $305 / 430 \pm 2$ & $338 \pm 3 / 436 \pm 4$ & $280 / 331 \pm 3$ & $280 / 338 \pm 2$ \\
\hline & 4 & 44 & $318 \pm 3 / 427 \pm 1$ & $337 \pm 3 / 434 \pm 1$ & $280 / 330 \pm 1$ & $280 / 336 \pm 3$ \\
\hline & 7 & 92 & $310 / 427 \pm 6$ & $340 / 437 \pm 3$ & $280 / 329 \pm 1$ & $280 / 335 \pm 1$ \\
\hline & 10 & 141 & $310 / 431 \pm 7$ & $340 / 434 \pm 2$ & $280 / 327 \pm 2$ & $282 \pm 3 / 342 \pm 1$ \\
\hline & 13 & 176 & $310 \pm 5 / 428 \pm 3$ & $342 \pm 3 / 438 \pm 4$ & $280 / 328 \pm 1$ & $280 / 337 \pm 2$ \\
\hline
\end{tabular}

ISI: Integrated solar intensity.

nd: not detected.

\pm : The standard deviation among triptlicate bottles.

day of irradiance $\left(22 \mathrm{MJ} \mathrm{m}^{-2}\right)$ caused the largest change in the blue-shift of the peak C. However, the peak position was almost unaltered under the dark condition during the 13-days incubation period (Figs. 3E and 3F, Table 2).

The FI of the peak $\mathrm{C}$ in upstream samples decreased rapidly over the control during the irradiance of $22 \mathrm{MJ}$ $\mathrm{m}^{-2}$ and then decreased more gradually during the rest of the incubation period (Figs. 4A and 4B). In the case of YR sample, the decrease in the FI of the peak $C$ was the largest between 22 and $44 \mathrm{MJ} \mathrm{m}^{-2}$ irradiance (Fig. 4C). The net decrease in FI at the peak $\mathrm{C}$ in irradiated samples was $72 \%$ in KG upstream, $84 \%$ in NM upstream, and $80 \%$ in YR downstream waters at the end of the experiment (Table 1). High degradation of FI during the initial period of the solar exposure has been reported (Del Vecchio and Blough, 2002). This phenomenon seems to be due to the decomposition of highly photosensitive fluorophores existing in the FA-like components in FDOM. Such fluorophores belong to the lowest energy band in a molecule and, accordingly, are very sensitive to solar irradiation (Senesi, 1990; Del Vecchio and Blough, 2002).

The FI of the peak $\mathrm{C}$ in the dark samples slightly increased by $6-15 \%$. Slight increases in the Ex/Em wave- lengths of the peak $\mathrm{C}$ position, i.e., red-shift, were found during the incubation period, although they were not significant (Table 2).

The Em wavelength of the peak $\mathrm{T}$ in the YR downstream sample was gradually shifted from $338 \mathrm{~nm}$ to 328 $\mathrm{nm}$ in irradiated samples, while the Ex wavelength was almost fixed during the irradiation (Table 2). In the dark samples, both Ex and Em wavelengths of the peak T were not changed. The FI at the peak T gradually decreased in irradiated samples while it hardly changed in dark samples (Fig. 4D). The total loss in FI at the peak T were about $59 \%$ in the YR sample after 13 days of solar irradiation (Table 1). Protein-like substances are usually considered to be microbiologically labile (Baker and Inverarity, 2004). However, the experimental results, obtained here, suggested that the protein-like substances in the YR sample were microbiologically refractory. Even though the filtration using glass fiber filter might eliminate most of microbes, the decrease in the DOC concentration under the dark condition clearly demonstrated the microbial degradation of dissolved organic matter in the YR sample (Fig. 2C). The decrease in the FI of the peak $\mathrm{T}$, therefore, did not directly associate with that in DOC concentration. The experimental results (Fig. 4D) sug- 

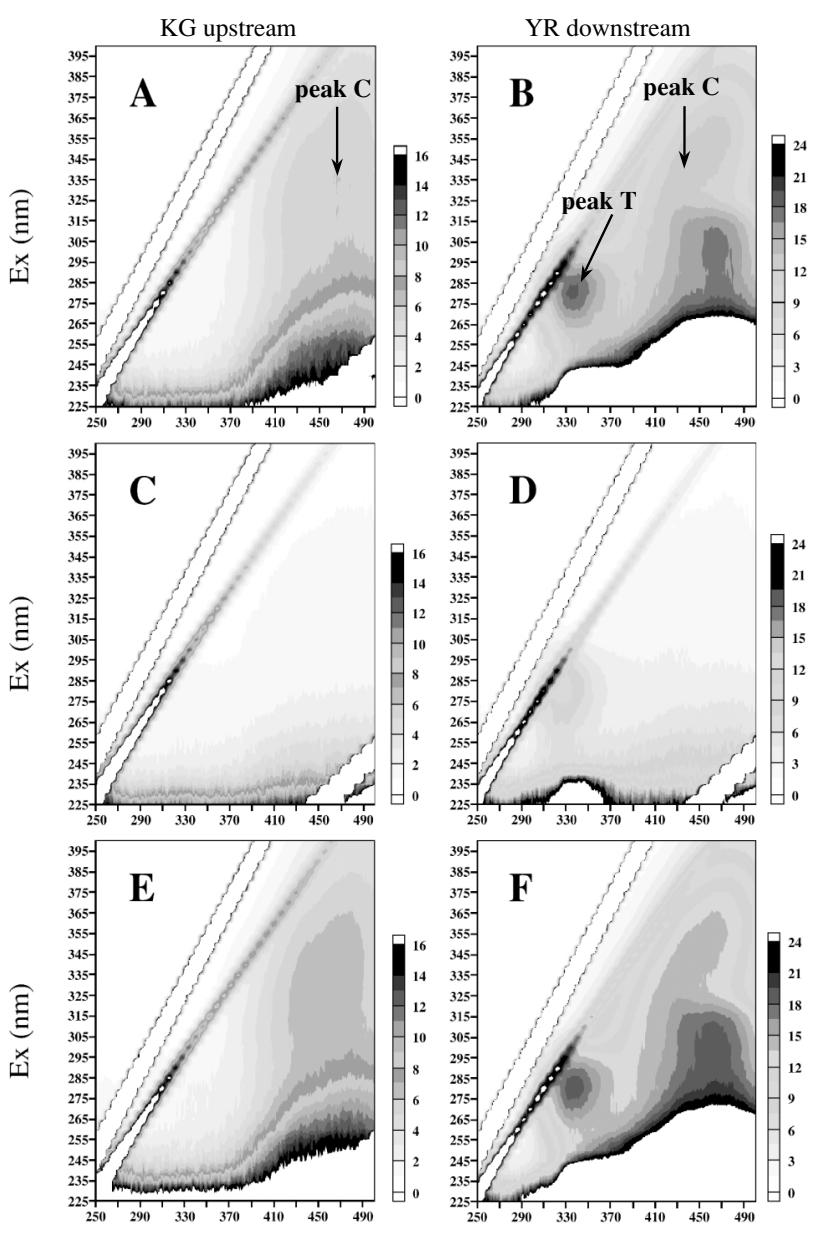

$\operatorname{Em}(\mathrm{nm})$
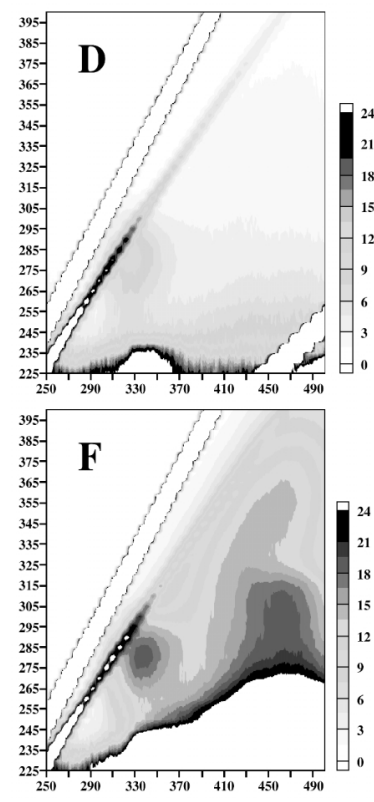

$\mathrm{Em}(\mathrm{nm})$

Fig. 3. Examples of the 3-D EEM in original ( $A$ and $B$ ), irradiated $(C$ and $D)$ and dark ( $E$ and $F$ ) samples showing the fulvic acid-like (peak $C$ ) and protein-like (peak $T$ ) fluorescence in the $K G$ upstream (left panels) and the YR downstream (right panels) waters, respectively.

gested that protein-like fluorescence in the YR sample were photodegradable, or at least, that the decrease in the peak $\mathrm{T}$ fluorescence required the irradiation. Volk et al. (1997) reported that amino acids bound with humic substances. Humic components may protect the protein-like components (or, amino acids) in such complexes to the microbial degradation. The decrease in FI of the peak T due to the irradiation was lower than that of the FA-like fluorescence (peak C) in the YR waters (Table 1). It suggested that the FDOM components containing proteinlike substances were less susceptible to photodegradation compared to those of FA-like components.

Although DOC concentration in the YR waters under dark condition was significantly decreased (16\%), FIs of peak $\mathrm{C}$ and peak $\mathrm{T}$ increased (Table 1). These results sug-

gested that the decrease in DOC concentration in the YR sample under the dark condition was not due to the degradation of FDOM.

\section{Kinetics of photodegradation}

Assuming a first-order kinetics for the photodegradation of DOM, the changes in FI and DOC due to irradiation can be expressed as follows.

$$
\begin{aligned}
& \operatorname{Ln}\left(F I / F I_{0}\right)=-a S \\
& \operatorname{Ln}\left(D O C / D O C_{0}\right)=-b S
\end{aligned}
$$

where, $a$ and $b$ are the reaction rate constants for photodegradation of FA-like FDOM and DOC, $F I_{0}$ and $D O C_{0}$ are the initial FI and DOC, and $S$ is the integrated solar energy $\left(\mathrm{MJ} \mathrm{m}^{-2}\right)$, respectively. The degradation of FDOM and DOC are clearly understood from the relations between the $S$ and $\operatorname{Ln}\left(F I / F I_{0}\right)$ (Figs. 5A, 5B and $5 \mathrm{C})$ and $\mathrm{Ln}\left(D O C / D O C_{0}\right)$ (Figs. 5D, 5E and 5F).

The degradation rates of the FA-like FI ( $a$ in Eq. (1)) were higher in the first 2-days of irradiation ( 44 MJ $\mathrm{m}^{-2}$ ) compared to those of the latter days (Figs. 5A, 5B and $5 \mathrm{C}$ ). The temporal change in the degradation rate might be explained by the existence of the two types of fluorophores in the FA-like component (Senesi, 1990; McKnight et al., 2001; Moran et al., 2000). One type is highly sensitive to irradiation, and another type is relatively less sensitive. One of high sensitive fluorophore is the Schiff-base derivatives $(-\mathrm{N}=\mathrm{C}-\mathrm{C}=\mathrm{C}-\mathrm{N}-$ ) detected in FA and HA in DOM, which shows a fluorescence peak at $\mathrm{Ex} / \mathrm{Em}=360-390 / 450-470 \mathrm{~nm}$ (Laane, 1984). Del Vecchio and Blough (2002) also suggested that the initial high losses in FI were caused by a discrete class of (fluorescent) chromophores, which are particularly sensitive to photodegradation. Although the Ex wavelength for the peak $C$ in the original upstream samples (Table 2) was shorter than that of the Shiff-base derivatives, it was suggested that the Schiff-base type fluorophore might be a candidate corresponding to the initial high loss in the FAlike FI under the light condition.

According to the model of the photodegradation of the FDOM obtained here, the FA-like FI changed nonlinearly with DOC concentration (Fig. 6). Mostofa et al. (2005b) found the direct proportion between DOC concentration and FA-like FI in upstream waters in the Lake Biwa watershed. On the other hand, in Lake Biwa, into which stream waters studied here flow, the DOC concentration was rather higher than that expected from the FAlike FI (Mostofa et al., 2005b). It was suggested that allochthonous FDOM might be photodegraded and mixed with autochthonous DOM in the lake (Mostofa et al., 2005b). However, Nguyen et al. (2005) showed that a green alga (Scenedesmus quadricauda) produced fulvic- 

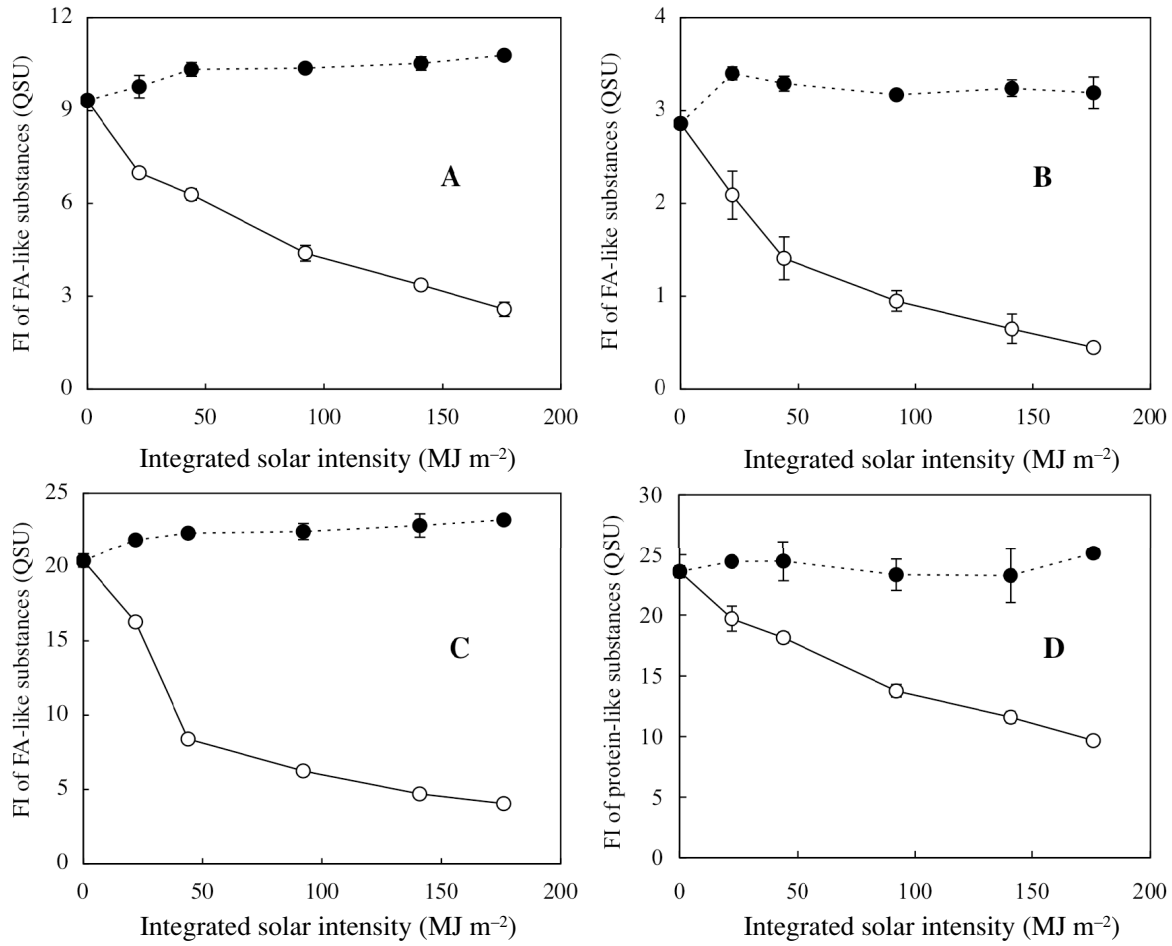

Fig. 4. Changes in the FI of FA-like ( $A, B$ and $C)$ and protein-like $(D)$ substances with integrated solar intensity.

$A$, the KG upstream; $B$, the NM upstream; $C$ and $D$, the YR downstream samples. Open circle, irradiated condition; closed circle, dark condition. The error bar indicates the standard deviation.
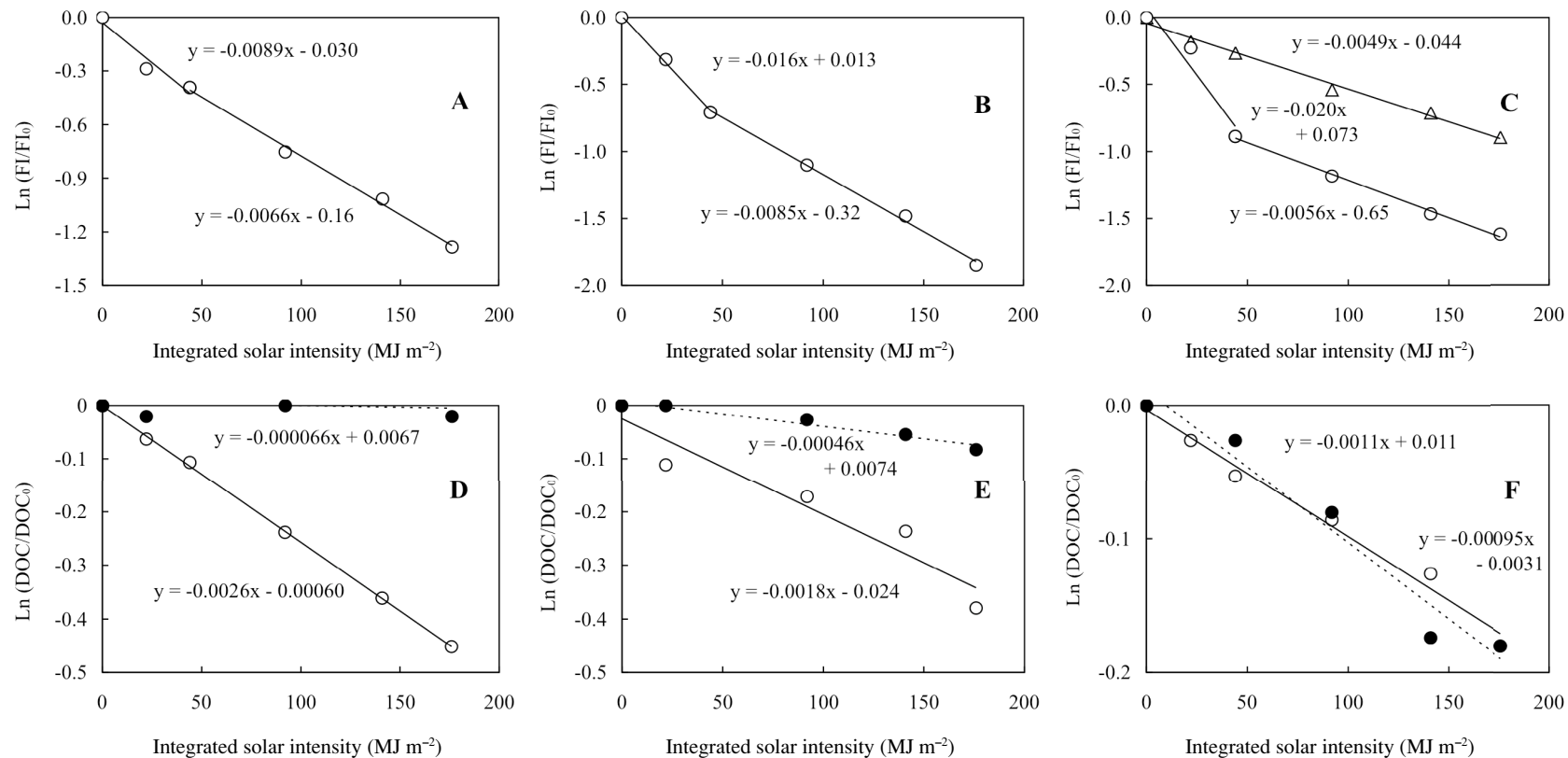

Fig. 5. Relationships between the $L n\left(F I / F I_{0}\right)$ and the integrated solar intensity $(A, B$ and $C)$ and between the $L n\left(D O C / D O C_{0}\right)$ and the integrated solar intensity $(D, E$ and $F)$. A and $D$, the KG upstream; $B$ and $E$, the NM upstream; $C$ and $F$, the YR downstream sample. Open circle, irradiated condition; closed circle, dark condition. Open triangle in $C$ shows the change in the protein-like FI under the irradiated condition. 


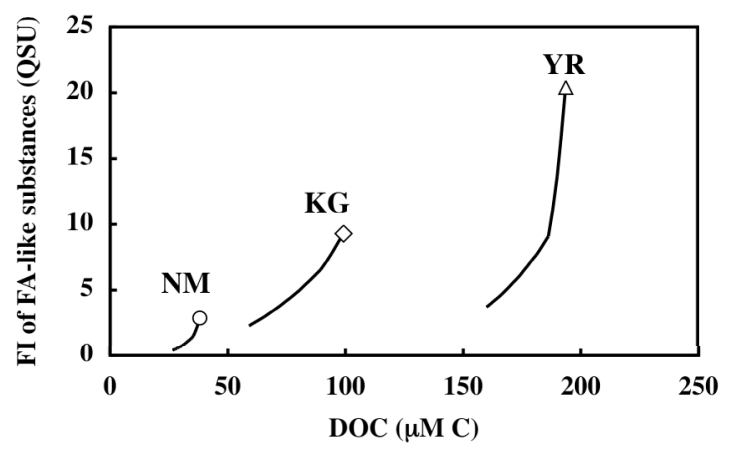

Fig. 6. Changes in DOC concentration and FA-like FI during photodegradation of DOM modeled by the first-order kinetics. Original DOC concentration and FI are presented as follows. Open circle, the NM upstream; open diamond, the KG upstream; open triangle, the YR downstream sample.

like fluorescent materials $(E x / E m=320-340 \mathrm{~nm} / 400$ $450 \mathrm{~nm}$ ). Therefore, the careful examination may be needed to study the origin and dynamics of FDOM in lentic environments such as lake and pond.

Photodegradation of the protein-like FI in the YR sample was linear during the experimental period (Fig. 5C). The degradation rate of the protein-like FI $\left(0.0049 \mathrm{MJ}^{-1}\right.$ $\mathrm{m}^{2}$ ) was similar to that of FA-like FI at the second phase of the photodegradation $\left(0.0056 \mathrm{MJ}^{-1} \mathrm{~m}^{2}\right)$. It might indicate that protein-like substances (or, amino acids) were closely associated with FA-like substances (Volk et al., 1997), or at least, that a same process contributed to the decreases in protein-like and FA-like fluorescence.

The two-step photodegradation kinetics in the FA-like FI was not found in the case of DOC (Figs. 5D, 5E and $5 F$ ). Degradation rates of upstream samples under the dark condition $\left(0.000066 \mathrm{MJ}^{-1} \mathrm{~m}^{2}\right.$ in $\mathrm{KG}$ and $0.00046 \mathrm{MJ} \mathrm{m}^{-2}$ in NM samples) were quite lower or negligible compared with those under the irradiation condition $(0.0026$ and $0.0018 \mathrm{MJ}^{-1} \mathrm{~m}^{2}$, respectively). Therefore, it was suggested that the upstream DOM was highly refractory to microbial degradation. The photodegradation rates of DOC in $\mathrm{KG}$ and NM samples were significantly lower than those of the FI. This indicates that DOC is less sensitive to irradiation compared with FDOM. The DOC degradation rate in the YR sample under the dark condition was almost as same as that under the irradiated condition. It suggested that the microbiologically labile DOC predominated at the downstream. The effect of the coexisting humic substances on the decrease in the protein-like fluorescence should be examined to understand the degradability of the freshwater DOM. It was suggested that the nature and composition of DOM were different between upstream and downstream river waters, with respect to the biological degradation as well as the photodegradation.
Acknowledgments-We thank Profs. E. Wada of Japan Agency for Marine-Earth Science, and Feng Chang Wu of Institute of Geochemistry, Chinese Academy of Sciences, for their encouragement during this study and manuscript preparation. This work was supported and financed by the Grant-in-Aids for Scientific Research (No. 09041159), for Scientific Research of Priority Area B (No. 11213101), and for the International Geosphere-Biosphere Programme (IGBP) at Nagoya University, from the Ministry of Education, Culture, Sports, Science and Technology (MEXT), Japan, and a grant from the Lake Biwa Research Institute, Shiga Prefecture.

\section{REFERENCES}

Amon, R. M. W. and Benner, R. (1996) Photochemical and microbial consumption of dissolved organic carbon and dissolved oxygen in the Amazon River system. Geochim. Cosmochim. Acta 60, 1783-1792.

Baker, A. (2001) Fluorescence excitation-emission matrix characterization of some sewage impacted rivers. Environ. Sci. Technol. 35, 948-953.

Baker, A. (2002a) Fluorescence excitation-emission matrix characterization of river waters impacted by a tissue mill effluent. Environ. Sci. Technol. 36, 1377-1382.

Baker, A. (2002b) Spectrophotometric discrimination of river dissolved organic matter. Hydrol. Process. 16, 3203-3213.

Baker, A. and Inverarity, R. (2004) Protein-like fluorescence intensity as a possible tool for determining river water quality. Hydrol. Process. 18, 2927-2945.

Baker, A. and Spencer, R. G. M. (2004) Characterization of dissolved organic matter from source to sea using fluorescence and absorbance spectroscopy. Sci. Total Environ. 333, 217-232.

Baker, A., Elliott, S. and Lead, J. R. (2007) Effects of filtration and $\mathrm{pH}$ perturbation on freshwater organic matter fluorescence. Chemosphere 67, 2035-2043.

Coble, P. G. (1996) Characterization of marine and terrestrial DOM in seawater using excitation-emission matrix spectroscopy. Mar. Chem. 52, 325-36.

Coble, P. G., Green, S. A., Blough, N. V. and Gagosian, R. B. (1990) Characterization of dissolved organic matter in the Black Sea by fluorescence spectroscopy. Nature 348, 432435.

Del Vecchio, R. and Blough, N. V. (2002) Photobleaching of chromophoric dissolved organic matter in natural waters: Kinetics and modeling. Mar. Chem. 78, 231-253.

Engelhaupt, E. and Bianchi, T. S. (2001) Sources and composition of high-molecular-weight dissolved organic carbon in a southern Louisiana stream (Bayon Trepagnier). Limnol. Oceanogr. 46, 917-926.

Hayakawa, K., Sekino, T., Yoshioka, T., Maruo, M. and Kumagai, M. (2003) Dissolved organic carbon and fluorescence in Lake Hovsgol: factors reducing humic content of the lake water. Limnology 4, 25-33.

Laane, R. W. P. M. (1984) Comment on the structure of marine fulvic and humic acids. Mar. Chem. 15, 85-87.

Leenheer, J. A. and Croue, J. P. (2003) Characterizing aquatic dissolved organic matter. Environ. Sci. Technol. 37, 18-26.

Malcolm, R. L. (1985) Geochemistry of stream fulvic and hu- 
mic substances. Humic Substances in Soil, Sediment, and Water: Geochemistry, Isolation and Characterization (Aiken, G. R., McKnight, D. M., Wershaw, R. L. and MacCarthy, P., eds.), 181-209, Wiley.

Malcolm, R. L. (1990) The uniqueness of humic substances in each of soil, stream and marine environments. Anal. Chim. Acta 232, 19-30.

Mann, R. M. and Boddy, M. R. (2000) Biodegradation of a nonylphenol ethoxylate by the autochthonous microflora in lake water with observations on the influence of light. Chemosphere 41, 1361-1369.

McKnight, D. M., Boyer, E. W., Westerhoff, P. K., Doran, P. T., Kulbe, T. and Andersen, D. T. (2001) Spectrofluorometric characterization of dissolved organic matter for indication of precursor organic material and aromaticity. Limnol. Oceanogr. 46, 38-48.

Moran, M. A. and Zepp, R. G. (1997) Role of photoreactions in the formation of biologically labile compounds from dissolved organic matter. Invited review. Limnol. Oceanogr. 42, 1307-1316.

Moran, M. A., Sheldon, W. M., Jr. and Zepp, R. G. (2000) Carbon loss and optical property changes during long-term photochemical and biological degradation of estuarine dissolved organic matter. Limnol. Oceanogr. 45, 1254-1264.

Mostofa, K. M. G. (2005) Dynamics, characteristics and photochemical processes of fluorescent dissolved organic matter and peroxides in river water. Ph.D. Thesis, Hiroshima University, Japan.

Mostofa, K. M. G., Honda, Y. and Sakugawa, H. (2005a) Dynamics and optical nature of fluorescent dissolved organic matter in river waters in Hiroshima prefecture, Japan. Geochem. J. 39, 257-271.

Mostofa, K. M. G., Yoshioka, T., Konohira, E., Tanoue, E., Hayakawa, K. and Takahashi, M. (2005b) Three-dimensional fluorescence as a tool for investigating the dynamics of dissolved organic matter in the Lake Biwa watershed. Limnology 6, 101-115.

Münster, U., Salonen, K. and Tulonen, T. (1999) Decomposition. Limnology of Humic Waters (Keskitalo, J. and Eloranta,
P., eds.), 225-263, Backhuy Publishers.

Nguyen, M.-L., Westerhoff, P. P. E., Baker, L., Hu, Q., EsparzaSoto, M. and Sommerfeld, M. (2005) Characteristics and reactivity of algae-produced dissolved organic carbon. $J$. Environ. Engineering 131, 1574-1582.

Ogawa, H., Amagai, Y., Koike, I., Kaiser, K. and Benner, R. (2001) Production of refractory dissolved organic matter by bacteria. Science 292, 917-920.

Senesi, N. (1990) Molecular and quantitative aspects of the chemistry of fulvic acid and its interactions with metal ions and organic chemicals. Part II. The fluorescence spectroscopy approach. Anal. Chim. Acta 232, 77-106.

Steinberg, C. E. W. and Münster, U. (1985) Geochemistry and ecological role of humic substances in lakewater. Humic Substances in Soil, Sediment, and Water: Geochemistry, Isolation and Characterization (Aiken, G. R., McKnight, D. M., Wershaw, R. L. and MacCarthy, P., eds.), 105-145, Wiley.

Vähätalo, A. V. and Wetzel, R. G. (2004) Photochemical and microbial decomposition of chromophoric dissolved organic matter during long (months-years) exposures. Mar. Chem. 89, 313-326.

Volk, C. J., Volk, C. B. and Kaplan, L. A. (1997) Chemical composition of biodegradable dissolved organic matter in streamwater. Limnol. Oceanogr. 42, 39-44.

Yamashita, Y. and Tanoue, E. (2003) Chemical characterization of protein-like fluorophores in DOM in relation to aromatic amino acids. Mar. Chem. 82, 255-271.

Yoshioka, T., Ueda, S., Khodzher, T., Bashenkhaeva, N., Korovyakova, I., Sorokovikova, L. and Gorbunova, L. (2002) Distribution of dissolved organic carbon in Lake Baikal and its watershed. Limnology 3, 159-168.

Yoshioka, T., Mostofa, K. M. G., Konohira, E., Tanoue, E., Hayakawa, H., Takahashi, M., Ueda, S., Katsuyama, M., Khodzher, T., Bashenkhaeva, N., Korovyakova, I., Sorokovikova, L. and Gorbunova, L. (2007) Distribution and characteristics of molecular size fractions of freshwater dissolved organic matter in watershed environments: Its implication to degradation. Limnology 8, 29-44. 